\title{
Krytyka neorepublikańskiej koncepcji wolności politycznej Philipa Pettita ${ }^{1}$
}

\author{
Katarzyna Eliasz \\ Uniwersytet Jagielloński w Krakowie \\ Katarzyna.eliasz@gmail.com
}

Otrzymano 7 grudnia 2017, zaakceptowano 21 stycznia 2018, opublikowano 26 kwietnia 2018.

\begin{abstract}
Abstrakt
Celem artykułu jest rekonstrukcja i krytyka koncepcji wolności politycznej przedstawionej na gruncie współczesnego instrumentalnego republikanizmu reprezentowanego przede wszystkim w pracach Philipa Pettita. Instrumentalny republikanizm zakłada, że wolność polityczna jest wartością instrumentalną, służącą realizowaniu naczelnej wartości, jaką jest wolność rozumiana jako nieobecność dominacji. Uznanie nie-dominacji za naczelną wartość pociąga za sobą postulat ograniczenia wolności politycznej, która - jak wskazuje Pettit - może być jednym ze źródeł dominacji (w związku z groźbą tyranii większości). W artykule wskazuję, że argumenty Pettita narażone są na dwa podstawowe zarzuty. Po pierwsze, w wyznaczonym przez niego (zbyt wąskim) zakresie, wolność polityczna nie sprzyja niedominacji. Po drugie, skupiając się wyłącznie na instrumentalnej roli wolności politycznej, Pettit pomija jej głębszy wymiar jako wartości demokratycznej.
\end{abstract}

Słowa kluczowe: wolność polityczna; nie-dominacja; instrumentalny republikanizm; arbitralność; wartość instrumentalna; Philip Pettit.

\section{Wprowadzenie}

Sformułowane ogólnie pojęcie wolności politycznej wydaje się jasne: jest to „udział ludzi w wyborze swojego rządu, w procesie legislacyjnym i w kontroli nad administracją" (von Hayek, 2006, s. 27); innymi słowy, wolność polityczna to przysługujące obywatelom prawo uczestniczenia we władzy publicznej. Tego rodzaju definicja jest jednak mglista,

\footnotetext{
${ }^{1}$ Niniejszy artykuł został opracowany w ramach projektu badawczego pod tytułem Miejsce wolności politycznej w hierarchii wartości demokratycznych finansowanego ze środków Narodowego Centrum Nauki przyznanych na podstawie decyzji DEC-2016/23/D/HS5/01814.
} 
bowiem postulat „uczestniczenia we władzy publicznej” może być wielorako interpretowany i różnie realizowany w praktyce demokratycznej, skutkując węższymi lub szerszymi koncepcjami wolności politycznej. Przykładem najszerszej koncepcji wolności politycznej jest tak zwana koncepcja „,populistyczna”. Jej zwolennicy, wśród których najbardziej znanym jest niewątpliwie Jan Jakub Rousseau, uznają, że lud posiada własną wolę, która może się ujawnić tylko wtedy, gdy obywatele bezpośrednio zabierają głos w sprawach politycznych. Wszelka reprezentacja utrudnia manifestowanie woli ludu i w konsekwencji ogranicza jego możliwość stanowienia o sobie samym (np. Riker, 1988, s. 11-12; Canovan, 2008, s. 134). Warto podkreślić, że termin „populizm” ma w tym kontekście specyficzne znaczenie; nie odnosi się do polityki schlebiającej pragnieniom ludu czy politycznej retoryki nawiązującej do jego preferencji. „Populizm” w omawianym tu znaczeniu jest terminem neutralnym i analitycznym, który oznacza „odwołanie się do «ludu» przeciwko rzekomym reprezentantom tego ludu" (Canovan, 2008, s. 93). Po drugiej stronie spektrum możliwości znajdują się koncepcje przyznające wolności politycznej węższy zakres i dopuszczające szerokie kompetencje politycznych przedstawicieli. W niniejszym tekście analizuję jedną z węższych koncepcji wolności politycznej, rozwijaną na gruncie współczesnego instrumentalnego republikanizmu, przede wszystkim w pracach Philipa Pettita. Zdaniem Pettita, aktywność obywatelska w sferze publicznej pełni wyłącznie instrumentalną funkcję, mianowicie - osiągania ideału wolności rozumianej jako nie-dominacja. Jak pokazuję w dalszej części tekstu, tak wąska koncepcja wolności politycznej narażona jest na kilka zarzutów, które można podzielić na „wewnętrzne” i ,zewnętrzne”. Formułując zarzuty wewnętrzne, wskazuję, że ograniczenie zakresu wolności politycznej nie sprzyja - wbrew tezom Pettita - realizowaniu ideału nie-dominacji. Mój główny zarzut zewnętrzny przyjmuje formę argumentu aksjologicznego, zgodnie z którym instrumentalny republikanizm prowadzi do pominięcia czy niedoceniania głębszej wartości wolności politycznej. Wąski zakres wolności politycznej, który proponuje Pettit, wynika właśnie z niedocenienia wartości wolności politycznej (im bowiem donioślejszą rolę przyznaje się wolności politycznej i im wyżej stawia się ją w hierarchii wartości politycznych, tym ex hypothesi szerszy powinien być jej zakres).

\section{Instrumentalny republikanizm}

Począwszy od lat 70. XX wieku, wraz z publikacjami autorów takich jak J. G. A. Pocock (1975), Quentin Skinner (1999, 2013) czy Philip Pettit (1997) republikanizm zyskał popularność jako koncepcja polityczna i interesująca alternatywa wobec dominującego do tej pory liberalizmu. Od tego czasu powstało wiele zasadniczo różniących się wersji republikanizmu, stąd trudno o przedstawienie jednej jego definicji. W tym tekście skupiam się na najczęściej dyskutowanym wariancie neorepublikanizmu, określanym jako in s t r u mentalny republikanizm (Patten, 1996, s. 26; Honohan, 2002, s. 8-9; Maynor, 2002). Pettit, niewątpliwie najbardziej uznany przedstawiciel tego nurtu, uznaje, że wolność polityczna jest wartością wyłącznie instrumentalną, służącą osiąganiu szczególnego rodzaju negatywnej wolności, którą określa mianem ni e-d o m in a c ji. 
Nie-dominacja jest w jego przekonaniu naczelną wartością republikańską i założeniem, które odróżnia republikanizm od innych koncepcji politycznych, przede wszystkim liberalizmu i obywatelskiego humanizmu (Pettit, 1997, s. 7-11). Istotę nie-dominacji najłatwiej jest uchwycić, zestawiając ją z koncepcją wolności negatywnej w znaczeniu, jakie nadał temu terminowi Isaiah Berlin.

W przekonaniu Berlina wolność negatywna ,jest po prostu sferą, w której człowiek może działać bez przeszkód ze strony innych ludzi”, a „mierzy się [ją] zazwyczaj zakresem, w jakim nikt nie ingeruje w naszą działalność” (Berlin, 1994, s. 182). Pettit i Skinner uważają, że taka definicja mylnie identyfikuje istotę wolności, co ukazują, przywołując scenariusz możliwych relacji między panem i niewolnikiem. Może być tak, że niewolnik będzie miał łaskawego pana nieingerującego w jego działania albo dzięki sprytowi nauczy się unikać ingerencji. Niewolnik ten, w sensie negatywnym, pozostawałby wolny. Jak jednak zauważają Pettit i Skinner, chociaż udaje mu się unikać ingerencji, potencjalnie pozostaje wciąż na nią narażony, ponieważ pan może arbitralnie ingerować w jego wybory, kiedy tylko zapragnie (Pettit, 1997, s. 22-23, 31; Skinner, 2013, s. 56-58). Do istoty $\mathrm{n}$ i e w o 1 i należy - zgodnie z tą interpretacją - bycie narażonym na a r b i t r a l ną ing e r e n c ję, zarówno fakty c zną, jak i potencjalną. Wolność rozumianą jako nieobecność zarówno potencjalnej, jak i faktycznej arbitralnej ingerencji, republikanie określają mianem nie-dominacji. Trzeba podkreślić, że w świetle powyższych założeń nie każdy akt ingerencji będzie miał dominujący charakter, tak jak w nie każdej sytuacji dominacji musi mieć miejsce faktyczna ingerencja (na przykład w scenariuszu pana i niewolnika; Pettit, 1997, s. 61-66). Aby zrozumieć, na czym polega istota dominacji, należy dokładniej przedstawić sens, jaki republikanie nadają kryterium ar b i t r a ln o ś ci.

Zgodnie z potocznym znaczeniem, ,arbitralność” znaczy tyle co „przypadkowość” lub „nieprzewidywalność”. To rozumienie arbitralności nie jest jednak przydatne w kontekście analizowanego tutaj problemu; osoba znajdująca się we władzy drugiego człowieka może przewidywać przyszłe akty dominacji, co jednak nie czyni jej mniej zniewoloną (Lovett, 2017). Frank Lovett, rozwijając koncepcję wolności jako nie-dominacji, proponuje dwie inne definicje (Lovett, 2010, s. 111-112). Zgodnie z pierwszą władza polityczna czy społeczna jest arbitralna, jeśli nie jest ograniczana przez reguły i instytuc j e powszechnie znane wszystkim członkom grupy, których dotyczą (a r b i t r a l n o ść pro c e d u ra lna). Zgodne z drugą definicją decyzje i działania polityczne są arbitralne, jeśli nie biorą pod uwagę istotnych interesów i przekonań osób, których dotyczą (arbitralność substa n cjalna). Wedle Pettita działania władzy zasługują na miano niearbitralnych tylko wtedy, gdy spełniają oba kryteria łącznie, a więc są ograniczone przez reguły i instytucje oraz uwzględniają istotne interesy i opinie osób, których dotyczą. Nasuwa się jednak pytanie, które interesy i opinie można uznać za istotne. Z pewnością nie chodzi tutaj o indywidualne, egoistyczne preferencje każdego człowieka. Przy takim rozumieniu interesów i opinii wiele reguł prawnych, chociażby podatkowych, miałaby charakter substancjalnie arbitralny, nawet jeśli spełniałyby wymogi proceduralnej niearbitralności. Dlatego aby kategoria interesu miała polityczne znaczenie, musi obejmować te preferencje, które każdy ma nie jako osoba prywatna, ale jako członek wspólnoty 
społeczno-politycznej (Pettit, 1997, s. 55-56; Maynor, 2002, s. 74-75). Konieczne jest również, aby uzasadnienie konieczności realizacji tych interesów opierało się na argumentach, które mógłby uznać każdy rozsądny i dobrze poinformowany uczestnik debaty publicznej (Pettit, 2001, s. 156).

Należy w tym miejscu zwrócić uwagę na jeszcze jeden aspekt relacji między wolnością jako nie-ingerencją a wolnością jako nie-dominacją. Otóż obie stanowią wariant negatywnej koncepcji wolności, ponieważ do ich istoty należy brak ingerencji. Jak jednak trafnie zauważa Ian Carter, nie-dominacja jest kwalifikowanym rodzajem nie-ingerencji (Carter, 2000, s. 434), ponieważ, primo, jak już wspomniano wyżej, tylko akty arbitralnej ingerencji mają charakter dominacji, i secundo, nie-dominacja jest to trwała nie-ingerencja (resilient non-interference), a jej trwałość zapewniana jest przez instytucje państwowe i szeroki wachlarz systemowych rozwiązań. Można dodać jeszcze trzeci powód uznania nie-dominacji za kwalifikowany rodzaj nie-ingerencji, mianowicie ten, iż do istoty niedominacji należy znajdowanie się w stanie niezależności od kogoś innego, niebycie narażonym na arbitralną ingerencję (a więc stan niewoli nie sprowadza się - jak twierdził Berlin - tylko do faktycznego doświadczania ingerencji).

Mając na uwadze powyższą charakterystykę nie-dominacji, można teraz jasno pokazać, dlaczego stanowi ona dla neorepublikanów centralną wartość polityczną, wokół której rozwijają swoje koncepcje. Otóż tak rozumiana nie-dominacja jest dla nich nie tylko ideałem stricte politycznym; ma ona również wartość jako osobiste dobro każdego obywatela. Jak bowiem zauważają Pettit i Skinner, podleganie czyjejś arbitralnej władzy wymusza na ludziach stosowanie pewnych schematów zachowania czy strategii pozwalających na unikanie ingerencji (Pettit, 1997, s. 86; Skinner, 2008, s. 93). Chodzi przede wszystkim o różne formy autocenzury. Przykładowo, brak sprawnie działających procedur antymobbingowych czy zapobiegających dyskryminacji w miejscu pracy sprawia, że pracownik z obawy przed dyskryminującymi zachowaniami przełożonego - będzie zmuszony stosować różne strategie minimalizujące ryzyko konfrontacji lub wszelkimi siłami będzie się starał mu przypodobać. W takiej sytuacji źródło dyskomfortu pochodzi nie tylko z samej ingerencji, ale również z konieczności przewidywania przyszłych ingerencji i obmyślania strategii pozwalających ich unikać - taki stan oznacza życie w ciągłej niepewności. Ten przykład pokazuje, że nie-dominacja ma nad nie-ingerencją przewagę, mianowicie ogranicza uczucie niepewności, konieczność przewidywania i autocenzury (Pettit, 1997, s. 85-90). Tak rozumiana wolność (to jest jako nie-dominacja) ma wartość dwojakiego rodzaju. Jest to wartość instrumentalna, jako że zapewnia możliwość działania nieograniczonego przez akty arbitralnej ingerencji ze strony państwa czy innych osób. Innymi słowy, znajdowanie się w stanie nie-dominacji jest środkiem służącym realizacji celu, jakim jest możliwość działania bez ryzyka, że nasze inicjatywy będą bezkarnie blokowane na czyjeś życzenie. Wydaje się jednak, że centralna rola przyznawana przez współczesnych republikanów wolności rozumianej jako nie-dominacja opiera się na silniejszym uzasadnieniu. Uprawnione wydaje się twierdzenie, że wolność jako nie-dominacja jest, przynajmniej w interpretacji Pettita, wa r toś c ią ko n s ty t u t y w ną (chociaż sam nie posługuje się tą kategorią; por. Pettit, 1997, s. 90-92). Wartość konstytutywną rozumiem 
tutaj nie tylko jako warunek realizacji jakiejś wartości samoistnej (a więc takiej, która jest celem samym w sobie, nieredukowalnym do wartości jakiegoś innego zjawiska), ale także jako stanowiącą ,część” owej wartości samoistnej. Bycie w stanie nie-dominacji jest wartością konstytutywną, ponieważ nie tylko umożliwia (w większym zakresie niż nie-ingerencja) realizację w pełni ludzkiego życia, ale stanowi też element samego pojęcia w pełni ludzkiego życia. Jak twierdzi Pettit, bycie zdominowanym zmniejsza prawdopodobieństwo bycia traktowanym jako osoba, która ma przekonania godne szacunku i uwagi, która posługuje się rozumem; opinie osób znajdujących się w stanie dominacji mogą być odrzucane przez osoby dzierżące nad nimi władzę bez namysłu i właściwego uzasadnienia ${ }^{2}$. Oczywiście tak rozumiana nie-dominacja jest wartością, która może być realizowana w mniejszym lub większym stopniu, przy czym osiągnięcie stanu absolutnej nie-dominacji jest niemożliwe, ma ona bowiem charakter ,idei regulatywnej”, pewnego politycznego ideału.

$\mathrm{W}$ dalszej części artykułu przedstawiam rozwiązanie problemu dominacji zaproponowane przez Pettita. Skupiam się w tym kontekście na dwóch przedstawionych powyżej źródłach dominacji, to jest arbitralności rozumianej proceduralnie i substancjalnie. Pozwoli mi to jasno pokazać, jaki zakres i funkcję przyznaje on wolności politycznej.

\section{Rola wolności politycznej w realizacji wolności jako nie-dominacji}

Republikanie uważają, iż prawidłowo zaprojektowany system instytucji politycznych i prawnych stanowi szczególnie skuteczne zabezpieczenie przed arbitralną ingerencją (dominacją). W tym miejscu widoczna jest wyraźna różnica między rolą przyznawaną prawu na gruncie myśli republikańskiej (podobną na gruncie klasycznego republikanizmu i, omawianego tutaj, instrumentalnego republikanizmu) a rolą prawa w niektórych wariantach myśli liberalnej. Dla liberałów, chociażby Benthama czy Hobbesa, prawo - chociaż konieczne - stanowi ingerencję w wolność jednostki. Hobbes uchwycił tę relację między prawem a wolnością, pisząc, że wolność poddanych ,zależy od milczenia prawa” (Hobbes, 2009, s. 306). Tak więc dla (niektórych) zwolenników nie-ingerencji prawo, nawet ograniczone i poddane odpowiedniej kontroli, zawsze stanowi formę przymusu, a więc ograniczenie wolności. Natomiast dla zwolenników nie-dominacji prawo, nawet kiedy ingeruje w nasze wybory, nie stanowi formy ograniczenia wolności, o ile nie ma charakteru arbitralnego (w wymiarze substancjalnym i proceduralnym). Takie niearbitralne prawo jest postrzegane bardziej w kategoriach przeszkód naturalnych niż formy przymusu (Pettit, 1997, s. 84). W kwestii podejścia do prawa różnica między obiema koncepcjami jest więc subtelna i sprowadza się do tego, że zwolennicy koncepcji nie-dominacji nie

\footnotetext{
${ }^{2}$ Moją interpretację potwierdza następujący cytat: „To be a person is to be a voice that cannot properly be ignored, a voice which speaks to issues raised in common with others and which speaks with certain authority: enough authority, certainly, for discord with that voice to give others reason to pause and think. To be treated properly as a person, then, is to be treated as a voice that cannot be dismissed without independent reason: to be taken as someone worth listening to. The condition of domination would reduce the likelihood of being treated as a person in this way, so far as it is associated with a need for strategy and a subordinate status" (Pettit, 1997, s. 91).
} 
przeciwstawiają ex definitione prawa i wolności: uznają, że prawo i instytucje państwowe, chociaż ingerują w sferę możliwych ludzkich wyborów, nie naruszają wolności (przypomnijmy: kiedy te ingerencje nie mają charakteru arbitralnego; zob. Eliasz, Załuski, 2017). Takie niearbitralne prawo musi regulować dwie dziedziny życia, w których występować mogą różne formy dominacji: dziedzinę społeczną, a więc relacje między obywatelami ( $d o-$ minium), i dziedzinę publiczną, relację między obywatelami a władzą (imperium; Pettit, 1997, s. 13). Groźba dominacji w sferze dominium jest tym mniejsza, im większą osobistą niezależnością mogą cieszyć się obywatele; osiągnięcie nie-dominacji w kontekście społecznym wymaga więc rozwiązań na wielu płaszczyznach. Aby człowiek mógł cieszyć się osobistą niezależnością, musi mieć środki wystarczające dla godnego życia, możliwość edukacji, opieki zdrowotnej i ochrony prawnej (Pettit, 1997, s. 158-165). Realizacja postulatu nie-dominacji wymaga więc również przyjęcia jakiegoś wariantu sprawiedliwości dystrybucyjnej (na przykład zdaniem Lovetta ryzyko dominacji zmniejszyłoby wprowadzenie bezwarunkowego dochodu podstawowego [Lovett, 2012, s. 196-200]). Zabezpieczenie przed arbitralnymi działaniami władzy (sfera imperium) wymaga przede wszystkim, aby niemożliwe było kumulowanie jej w jednych rękach. Tradycyjnie republikanie postulowali konieczność wprowadzenia mieszanego systemu rządów oraz mechanizmów wzajemnej kontroli i podziału władz, podkreślali również znaczenie rządów prawa. Konieczne jest także, aby prawo, w zakresie, w jakim reguluje podstawowe uprawnienia i wolności obywateli oraz sposób funkcjonowania państwa, nie poddawało się łatwym zmianom na życzenie każdorazowej większości (Pettit, 1997, s. 180-183). Wszystkie skrótowo opisane powyżej zasady sprzyjają zapewnianiu proceduralnej niearbitralności.

Z punktu widzenia celów niniejszego tekstu dużo bardziej interesujący jest jednak rozwijany przez Pettita postulat zapewnienia substancjalnej niearbitralności, a więc uwzględniania opinii i interesów obywateli. Jego rozwiązanie zakłada bowiem wyraźne ograniczenie zakresu wolności politycznej (rozumianej jako obywatelska partycypacja) i przypisanie jej wyłącznie instrumentalnej funkcji. Warunkiem realizacji postulatu niearbitralności jest zapewnienie obywatelom okazji dla wyrażenia opinii i interesów. W przekonaniu Pettita gwarantują ją okresowe wybory, podczas których każdy obywatel, oddając głos, wskazuje kandydata, który jego zdaniem najlepiej zrealizuje jego interesy. Ryzyko utraty władzy w kolejnych wyborach zmusza polityków do wsłuchiwania się w preferencje obywateli i wywiązywania się z obietnic wyborczych, zabezpieczając w ten sposób realizację demokratycznie wyrażonych interesów (Pettit, 1999, s. 173; 2001, s. 161). Obietnica złożona obywatelom przy urnach nie jest jednak wystarczająca, nie tylko dlatego, że obietnice wyborcze często tracą ważność zaraz po wyborach; także dlatego, że demokratycznie wybrana władza może realizować wolę większości kosztem dyskryminowania przegranej mniejszości albo też podejmować inne działania wbrew interesom i życzeniom swoich wyborców. W pierwszym wypadku mamy do czynienia z ,tyranią demokratycznej większości”, w drugim z „tyranią demokratycznej elity” (Pettit, 2001, s. 162). Dobrze urządzona demokracja, którą Pettit określa mianem de mok r a ji k o n te st a c yjnej (Pettit, 1999, s. 178 i nast.; 2001, s. 164-167), przewiduje jednak instytucje umożliwiające zapobieganie obu typom „tyranii”. Obywatele, których interesy 
są zagrożone lub naruszane, mogą indywidualnie, za pośrednictwem instytucji takich jak sądy, trybunały czy Rzecznik Praw Obywatelskich przeciwdziałać dyskryminującym prawom (Pettit, 1999, s. 181; 2012, s. 215-218). Możliwość kontestowania decyzji politycznych nie ogranicza się jednak do działań zapośredniczonych przez instytucje; Pettit uzupełnia katalog mechanizmów kontestacyjnych o formy obywatelskiego sprzeciwu takie jak pokojowe zgromadzenia (Pettit, 2012, s. 229-231; 2014, s. 133). Wolność polityczna rozumiana jako obywatelska partycypacja ma więc według Pettita dwojaką funkcję. Po pierwsze, stanowi główny sposób zapewniania substancjalnej niearbitralności. Po drugie, umożliwia wyrażanie sprzeciwu wobec potencjalnie dominujących poczynań władzy (chociaż wydaje się, że tę funkcję mają pełnić przede wszystkim wymienione wcześniej instytucje; formom obywatelskiego sprzeciwu Pettit nie poświęca wiele uwagi). Rola wolności politycznej jest więc w myśli Pettita wyłącznie instrumentalna, nie posiada - w jego mniemaniu - głębszej (samoistnej) wartości. To ograniczanie wynika najprawdopodobniej z obawy przed konsekwencjami powierzenia ludowi zbyt dużej władzy. Jak podkreśla Pettit, tyrania większości jest ostateczną formą arbitralności, a więc dominacji (Pettit, 1997, s. 8). W dalszej części tekstu przedstawiam argumenty krytyczne wobec zarysowanej wyżej (zbyt wąskiej) koncepcji wolności politycznej.

\section{Zarzuty wobec wąskiej koncepcji wolności politycznej}

\subsection{Zarzut nadmiernej wiary w możliwość manifestowania interesów drogą wyborów}

Z powyższej rekonstrukcji proponowanych przez Pettita strategii przeciwdziałania arbitralności substancjalnej wynika ograniczenie roli wolności politycznej do manifestowania interesów i opinii w drodze demokratycznych wyborów. Wniosek taki opiera się na przyjętym przez niego implicite założeniu, że decyzje wyborcze faktycznie odzwierciedlają istotne interesy obywateli, a więc, że podejmowane są zwykle w sposób racjonalny. Będę argumentować, że ten wniosek jest - przynajmniej częściowo - błędny, to jest, że decyzje wyborcze nie stanowią precyzyjnej manifestacji interesów wyborców i - w konsekwencji - że rozszerzenie zakresu wolności politycznej jest konieczne, aby możliwe było realizowanie substancjalnej niearbitralności, a tym samym republikańskiego ideału niedominacji. Otóż można wskazać trzy modele racjonalności wyborcy: model wyborcy nieracjonalnego (podejmującego decyzje w sposób nieświadomy), model wyborcy o ograniczonej, ale wystarczającej racjonalności (częściej podejmującego decyzje w sposób nieświadomy niż świadomy) i model wyborcy w pełni racjonalnego (podejmującego wyłącznie świadome decyzje; Załuski, 2015, s. 205-207). Zgodnie z założeniem o nieracjonalności wyborcy decyzje wyborcze podejmowane są przede wszystkim w oparciu o heurystyki, a więc uproszczone metody wnioskowania. Decyzje wyborcze opierają się na heurystykach takich jak ideologia polityczna (na przykład poglądy bardziej lewicowe lub prawicowe), preferencje większości czy miejsce na liście wyborczej (Załuski, 2015, s. 210-211). Podejmując decyzję w oparciu o heurystykę, wyborca nie poddaje dokładnej 
analizie programu politycznego w celu wybrania osoby lub partii, która w jego przekonaniu najlepiej zrealizuje jego interes; opiera się raczej na emocjach, które wywołuje w nim dany kandydat. Obraz wyborcy nieracjonalnego, a więc dokonującego wyboru wyłącznie w oparciu o heurystyki, jest jednak nadmiernie pesymistyczny, ponadto jego przyjęcie podważyłoby zasadność demokratycznego sposobu podejmowania decyzji politycznych. Również model wyborcy w pełni racjonalnego jest $\mathrm{z}$ dwóch powodów nie do przyjęcia. Po pierwsze, wyborcy zwykle nie mają wszystkich danych koniecznych do podjęcia decyzji w pełni racjonalnej. Po drugie, nawet gdyby posiadali wszystkie konieczne informacje, uwzględnienie ich w procesie decyzyjnym, ze względu na ich ilość, przerosłoby ich zdolności poznawcze. Dlatego najbardziej uzasadniony wydaje się model wyborcy o ograniczonej, ale wystarczającej racjonalności. Zakłada on, że wyborcy podejmują decyzje zarówno nieświadomie (opierając się na heurystykach), jak i świadomie. Przy czym decyzje świadome podejmowane są zgodnie z modelem satysfakcji, co znaczy, że wyborca głosuje na kandydata, który wydaje mu się ,akceptowalny”, a nie ,idealny” (Załuski, 2015, s. 212). Omówiony w tym miejscu schemat podejmowania decyzji wyborczych wskazuje, że obywatele głosują wystarczająco racjonalnie, aby uznać prawomocność procedur demokratycznych, ale obecny w procesie decyzyjnym element nieracjonalności pozwala postawić tezę, że decyzje podejmowane podczas wyborów nie stanowią dokładnej manifestacji interesów obywateli. Tym samym nie spełniają (albo spełniają w sposób nieidealny) funkcji, która w przekonaniu Pettita jest konieczna dla realizacji ideału nie-dominacji.

\subsection{Zarzut ograniczania ,autorskiej” roli obywateli}

Jak zauważają krytycy instrumentalnego republikanizmu, i co zresztą dostrzega sam Pettit, rola obywateli w przedstawionym przez niego modelu „demokracji kontestacyjnej” ogranicza się do działań „edytorskich” (Honohan, 2002, s. 236; Maynor, 2006, s. 128; Hamilton, 2014, s. 57). Obywatele są jedynie ,pośrednimi autorami” polityki, gdyż ich rola ogranicza się do wskazania przedstawicieli realizujących interesy uznawane przez nich za istotne, a wyrażane w wyborach powszechnych (Pettit, 2001, s. 161) albo do kontestowania potencjalnie dominujących działań władzy (zob. np. Lüders, Müller-Salo, 2016, s. 118-119). Postulat nie-dominacji, opierający się na założeniu, że działania władzy uwzględniają interesy obywateli, wymaga jednak, aby mieli szerszy zakres uprawnień „autorskich”. John Maynor, dostrzegając ograniczenia propozycji Pettita, sugerował, aby rozszerzyć zakres roli obywateli przez wprowadzenie instytucji umożliwiających powszechną deliberację. Katalog instytucji Maynora jest dosyć ogólny, wskazuje raczej kierunek niż konkretne rozwiązania. Proponuje między innymi wykorzystanie możliwości głosowania przez Internet, dyskusje z udziałem przedstawicieli władz, różne rodzaje konsultacji obywatelskich, dzięki którym rozszerzyłaby się „,autorska” rola obywateli (Maynor, 2006, s. 129-132). Postulat przyznania obywatelom większego udziału we współtworzeniu władzy jest jak najbardziej słuszny, ale realizowany - w moim przekonaniu - zbyt powściągliwie. Podkreślając naczelną wartość nie-dominacji, republikanie 
obawiają się szerokiego udziału obywateli we władzy ze względu na groźbę ,tyranii większości”, którą w ich przekonaniu ze sobą niesie. Groźba ta jest jednak przez nich demonizowana. Po pierwsze, jak zauważa sam Pettit (a o czym pisałam wcześniej), nawet ograniczenie wolności politycznej do samego udziału w wyborach nie oddala ryzyka ,tyranii demokratycznej większości”. Jest więc ono niejako wpisane w scenariusz demokratycznego podejmowania decyzji. Wymóg jej ograniczania jest natomiast racją dla istnienia różnych instytucji kontestacyjnych. Po drugie, istnieje wiele form partycypacji obywatelskiej, przy czym część z nich nie służy podejmowaniu wiążących decyzji politycznych. Niewiążące referenda, plebiscyty, konsultacje obywatelskie, a nawet pokojowe manifestacje gwarantowane przez wolność zgromadzeń są formami manifestowania opinii i interesów, pozwalającymi obywatelom pośrednio i w ograniczonym zakresie proponować kierunek działań legislacyjnych - tym samym nie zwiększają ryzyka „tyranii większości”.

Groźba tej - jak to określił Pettit - „ostatecznej formy arbitralności” (Pettit, 1997, s. 8) nie jest jednak jedynym zarzutem podnoszonym wobec postulatu szerokiego zakresu wolności politycznej i zwiększenia „,autorskich” uprawnień obywateli. Często podnoszony jest również ,argument z niekompetencji”, zgodnie z którym obywatele, nie znając skomplikowanych mechanizmów działania instytucji politycznych i nie umiejąc przewidzieć potencjalnych skutków reform, nie powinni dysponować zbyt szerokimi uprawnieniami „autorskimi”. Tak rozumiana teza o niekompetencji częściowo pokrywa się z założeniem modelu wyborcy o niepełnej, ale wystarczającej racjonalności. Chciałabym jednak podkreślić, że zarzut niekompetencji nie powinien być wykorzystywany w celu argumentowania na rzecz tezy o ograniczeniu autorskich uprawnień obywateli. Przede wszystkim nieracjonalność obywateli ujawnia się przede wszystkim wtedy, kiedy uczestniczą oni w cyklicznych wyborach i podejmują decyzje wyborcze o wyborze określonego kandydata czy partii. Taki wybór, aby był w pełni racjonalny, wymagałby zebrania znacznej ilości informacji, dlatego też w tym przypadku częściej stosowane są nieświadome mechanizmy rozumowania, takie jak heurystyki. Kiedy jednak decyzja polityczna dotyczy bardziej konkretnego problemu, jak w przypadku referendów czy plebiscytów, to ex hypothesi obywatelowi łatwiej zaangażować się na tyle, aby zebrać informacje konieczne do podjęcia w pełni racjonalnej decyzji. Trzeba też zwrócić uwagę, że postulat rozszerzenia ,,autorskich” uprawnień obywateli nie opiera się na założeniu, że mają oni proponować określone strategie rozwiązywania problemów. Ich rola sprowadza się raczej do komunikowania istotnych interesów i wyrażania opinii politycznych. Taka aktywność obywatelska nie wymaga żadnych szczególnych kompetencji. Dostateczną wiedzę na temat problemów własnego kraju ma każdy obywatel, który doświadcza ich na własnej skórze. Na pozorność wymogu kompetencji w kontekście identyfikowania problemów wymagających rozwiązania w następujący sposób zwraca uwagę Arystoteles:

Właściwy wybór jest bowiem rzeczą znawców, a więc wybór geometry rzeczą zajmujących się tą umiejętnością, a wybór sternika rzeczą znających się na sterowaniu. Bo jeśli nawet niektórzy z niefachowców wyznają się w pewnych pracach i sztukach, to przecież nie lepiej od ludzi znających się na rzeczy. Toteż, idąc za tym rozumowaniem, nie należałoby powierzać ludowi nieograniczonej władzy ani co do wyboru urzędników, ani co do ich kontroli. 
Może jednak nie wszystkie te zastrzeżenia są słuszne [...] - bo poszczególny człowiek może być wprawdzie gorszym sędzią od znawców, ale wszyscy razem zebrani albo będą lepsi, albo przecież nie gorsi - następnie też i dlatego, że w niektórych rzeczach wykonawca nie jest ani jedynym, ani najlepszym sędzią, jak w tych wypadkach, gdzie na wykonanej pracy wyznają się i niefachowcy. A więc np. ocena domu nie należy jedynie do tego, który go budował, lecz lepiej nawet osądzi go ten, który z niego korzysta (a tym jest pan domu). (Arystoteles, 2011, 1282a)

Krótko mówiąc, oba argumenty, to jest zarzut tyranii większości i zarzut niekompetencji, są jedynie częściowo trafne; nie podważają w każdym razie postulatu rozszerzenia ,autorskich" kompetencji obywateli w procesie kształtowania polityki prawa.

\subsection{Zarzut aksjologiczno-antropologiczny}

Powyżej wskazałam, że dla zwolenników instrumentalnego republikanizmu wolność polityczna jest wartością stricte instrumentalną sprzyjającą osiąganiu nie-dominacji. Jest to jednak słabe uzasadnienie wolności politycznej jako wartości demokratycznej (wynika z niego bowiem, że wartość ta jest pochodna wobec wartości, jaką przyznają nie-dominacji). Tymczasem wolność polityczna nie jest tylko sposobem gromadzenia informacji o interesach czy jedną z form kontestacji decyzji politycznych, ale też istotną formą ludzkiej aktywności służącą rozwijaniu ważnych społecznie cech, takich jak poczucie odpowiedzialności czy solidarności, oraz wyrażaniu własnych poglądów i konfrontowaniu ich z opiniami innych (Dagger, 1997, s. 134-135; Honohan, 2002, s. 217-218). Zwolennicy instrumentalnego republikanizmu zdają się podchodzić z rezerwą do postulatu przyznania wolności politycznej takiej głębszej wartości, ponieważ oznaczałoby to konieczność przyznania jej szerszego zakresu (czego, ze względu na ryzyko „tyranii większości” nie chcą czynić).

Teza o nieinstrumentalnej wartości wolności politycznej może przybierać dwie formy: argumentu antropologicznego i argumentu socjologiczno-psychologicznego. Na gruncie pierwszego z nich, wolność polityczna jest szczególnie wartościową aktywnością pozwalającą na pełną realizację natury ludzkiej. Na gruncie drugiego, korzystanie z wolności politycznej nie jest głównym warunkiem wartościowego czy „w pełni ludzkiego” życia, ale jest jednym z remediów na niekorzystne zjawiska psychologiczne typowe dla demokracji: „niezdrowe” zamiłowanie do równości czy egoizm. Zgodnie z tym ujęciem, wolność polityczna również ma wartość instrumentalną, ale jest to wartość głębsza, konieczna dla funkcjonowania społeczeństwa.

Najsłynniejszą zwolenniczką pierwszego podejścia jest Hannah Arendt. Opierając się na założeniach antropologicznych, doszła ona do wniosku, że wolność polityczna, którą rozumie szeroko, jako ws pólne działanie w przestrzeni publicznej (dyskutowanie, przedstawianie argumentów), jest najdoskonalszym sposobem realizacji natury czy raczej, zgodnie z terminologią Arendt, „kondycji ludzkiej”. Działanie jest w myśli Arendt szeroką kategorią obejmującą interakcje międzyludzkie, które jednak nie mają charakteru rutynowego, a wymagają inicjatywy i osobistego zaangażowania (Canovan, 2002, s. 131). Uwarunkowania, które działanie ma realizować to fakt wielości („to, że ludzie, 
a nie Człowiek żyją na Ziemi i zamieszkują świat" [Arendt, 2010, s. 25]) i zdolność spontaniczności, a więc inicjowania zmian, wpływania na otoczenie. Te główne uwarunkowania „kondycji ludzkiej” nie mogą być realizowane indywidualnie lub wyłącznie w przestrzeni prywatnej. Jak zauważa Arendt:

Wieść żywot całkowicie prywatny oznacza przede wszystkim być pozbawionym rzeczy niezbędnych do prawdziwie ludzkiego życia: być pozbawionym rzeczywistości, która bierze się z bycia widzianym i słyszanym przez innych, „obiektywnej” więzi z nimi, która bierze się z bycia z nimi związanym i z bycia od nich oddzielonym za pośrednictwem wspólnego świata rzeczy, być pozbawionym możliwości osiągania czegoś trwalszego od samego życia. Deprywacyjny charakter prywatności polega na nieobecności innych; jeśli chodzi o nich, człowiek wiodący życie czysto prywatne nie pojawia się, a zatem jest tak, jakby nie istniał. Cokolwiek robi, nie ma to znaczenia ani następstw dla innych ludzi, a to, co jest istotne dla niego, ich nie obchodzi. (Arendt, 2010, s. 79; wyróżnienie moje)

Powyższy cytat wskazuje, że - w przekonaniu Arendt - wolność polityczna jest wartością konstytutywną, pozwalającą na realizację w pełni ludzki e go ży c ia. Jest to szczególnie silne uzasadnienie, gdyż wartość wolności politycznej w tym ujęciu jest c a łk i e m niezależna od celu, który realizuje: „Spełnienie jest tutaj zawarte w samym wykonaniu, nie zaś w ukończonym produkcie” (Arendt, 2011, s. 187). Przyjęcie w całości argumentów Arendt może być z wielu powodów kłopotliwe. Po pierwsze, jej koncepcja zakłada, że działanie w sferze publicznej jest aktywnością stanowiącą warunek dobrego życia, a obywatelskie zaangażowanie jest cnotą perfekcjonistyczną. Przyznanie działaniu politycznemu takiej godności jest jednak trudne do przyjęcia, bowiem pośrednio podważa wartość innych stylów życia (na przykład życia poświęconego kontemplacji). Tym samym koncepcja Arendt kłóci się z zasadą równego szacunku i powiązaną z nią ideą neutralności. Dla zwolenników idei neutralności światopoglądowej państwa do przyjęcia jest jedynie republikanizm instrumentalny, przyznający cnocie obywatelskiej funkcję czysto polityczną, a więc traktujący ją jako warunek konieczny dla osiągania wartości politycznych (na przykład społeczeństwa wolnego od dominacji), a nie określonej wizji dobrego życia (np. Larmore, 2008, s. 178; Rawls, 2012, s. 284-286; Ciszewski, 2017). Po drugie, obiekcje może budzić założenie, zgodnie z którym wartość wolności politycznej jest nieredukowalna do jej instrumentalnych celów. Aktywność polityczna niewątpliwie stanowi źródło satysfakcji, ale sam impuls dla zaangażowania w politykę nie pochodzi z przekonania, że tylko tym sposobem można osiągnąć w pełni ludzkie życie. Poczucie satysfakcji jest pochodne wobec celów, które działanie polityczne realizuje, a więc zależy od możliwości wspólnego podejmowania decyzji czy manifestowania swoich opinii politycznych (zob. np. Elster, 1986, s. 125-127). Aby uniknąć powyższych zarzutów, można przyjąć bardziej „minimalistyczną” wersję argumentu o głębszej wartości wolności politycznej i uznać ją za szczególnie istotną formę ekspresji, której znaczenie nie jest wyłącznie wąsko instrumentalne, ale również nie stanowi warunku dobrego życia. Taki rodzaj „trzeciej drogi” odnaleźć można w rozważaniach Alexisa de Tocqueville’a. 
Najciekawszym wkładem Tocqueville'a w myśl polityczną jest niewątpliwie analiza skutków demokracji, szczególnie demokracji z silnie wyeksponowanym komponentem równościowym, na obyczaje obywateli. Demokracja, której towarzyszy zamiłowanie do równości w każdej dziedzinie życia i pragnienie dobrobytu, „wytwarza” w obywatelach niepożądane cechy, takie jak skłonność do zawiści czy, specyficznie przez niego rozumiany, indywidualizm wspierany przez „fikcję samowystarczalności”. Mechanizm ich powstawania charakteryzuje następująco: równość możliwości i świadomość wyłącznej odpowiedzialności za własny los sprawia, że obywatele czują, iż

nikomu nic nie zawdzięczają i od nikogo niczego nie oczekują; przywykli do tego, by myśleć o sobie, i są przekonani, że ich los leży w ich własnych rękach. [...] Demokracja stale sprowadza człowieka do niego samego i może go skazać na całkowite zamknięcie w kręgu własnej samotności. (Tocqueville, 1976, s. 340)

Tak rozumiana „fikcja samowystarczalności” wzmacniana pragnieniem dobrobytu sprawia, że energia obywateli skupia się na zaspokajaniu własnych, zwykle materialnych potrzeb. W ten sposób powstaje indywidualizm, który Tocqueville rozumie jako

uczucie spokojne i umiarkowane, które sprawia, że każdy obywatel izoluje się od zbiorowości i trzyma się na uboczu wraz ze swą rodziną i przyjaciółmi. Stwarzając sobie w ten sposób na własny użytek swoje małe społeczeństwo, pozostawia wielkie społeczeństwo jego własnym losom. (Tocqueville, 1976, s. 339)

Kolejnym „efektem ubocznym” demokracji z silnym elementem równościowym jest typowe wśród obywateli uczucie zawiści. Powszechna równość sprawia, że widok najmniejszej nawet nierówności jest trudny do zniesienia (Tocqueville, 1976, s. 157; Elster, 2009, s. 62). Wolność polityczna stanowi, w przekonaniu Tocqueville'a, remedium na te ,psychologiczne efekty uboczne demokracji”. Jej wpływ opisuje następująco:

Obywatele, zmuszeni do zajmowania się sprawami publicznymi, zostają wyrwani z kręgu spraw prywatnych i na pewien czas porzucają myśl o sobie. Z chwilą gdy wszystkie wspólne sprawy zaczynają być wspólnie rozważane, każdy człowiek zdaje sobie sprawę, że nie jest tak niezależny od innych, jak to sobie początkowo wyobrażał, oraz zaczyna pojmować, że aby zdobyć w innych oparcie, trzeba samemu ich wspierać. (Tocqueville, 1976, s. 342)

Mając na względzie powyższe uwagi, można zauważyć, że wolność polityczna nie pełni wyłącznie wąsko instrumentalnej funkcji, przez co rozumiem, że nie jest ona wyłącznie środkiem do osiągania politycznie istotnych celów czy narzędziem współrządzenia. Argumenty Tocqueville'a wskazują, że wolność polityczna co prawda jest wartością instrumentalną, ale pełniącą szczególnie doniosłą funkcję: stanowi remedium na negatywne efekty demokracji równościowej w dziedzinie życia społecznego. W kwestii wartości wolności politycznej można znaleźć u Tocqueville’a jeszcze jedną interesującą myśl, która stanowi trafne zamknięcie wątku aksjologicznego. Otóż zauważa on, że warunkiem trwałości wolności politycznej jest uznanie, że jest ona wartością samą w sobie:

Pojmuję, że u ludów źle rządzonych łatwo budzi się pragnienie, by rządzić się samodzielnie; ale takie umiłowanie niezależności, zrodzone ze szczególnego i przejściowego zła, które niesie ze sobą despotyzm, nigdy nie jest trwałe: przemija wraz z przyczyną, która mu dała istnienie; 
ludzie sądzą, że kochają wolność, tymczasem okazuje się, że jedynie nienawidzili władcy i pana. Złem, którego nienawidzą ludy stworzone do wolności, jest sama zależność. Nie sądzę też, by prawdziwe umiłowanie wolności mogło się zrodzić z samej nadziei na dobra materialne, jakie wolność przynosi, bo ta nadzieja często bywa zawodna. To prawda, że po dłuższym czasie wolność zawsze daje tym, co ją potrafią zachować, dobrobyt, a często bogactwo; ale zdarzają się okresy, w których wolność chwilowo utrudnia korzystanie z tych dóbr, a bywa i tak, że ich przejściowe używanie może zapewnić jedynie despotyzm. Ludzie, którzy w wolności cenili tylko takie dobra, nigdy jej długo nie zachowali (Tocqueville, 1994, s. 180-181).

Dalej zwraca uwagę, że wolność ma ,jej własny, od jej dobrodziejstw niezależny urok”, a ten ,kto w wolności szuka czegoś innego niż ona sama, ten został stworzony na niewolnika" (Tocqueville, 1994, s. 181). Nawet zwolenników traktowania wolności politycznej w sposób instrumentalny taki argument powinien przekonać, w każdym razie nie kłóci się on z ich założeniami. Jeśli jednak nie podziela się w pełni pesymistycznej diagnozy skutków demokracji równościowej, można przekonująco argumentować, że cenienie wolności politycznej za jej samoistną, ,wewnętrzną" wartość jest korzystne z perspektywy realizacji jej instrumentalnych zadań. Jak zauważa Michael Sandel, obywatele uznający wolność polityczną za wartość samoistną będą bardziej skorzy do idealistycznego działania politycznego motywowanego przede wszystkim troską o dobro wspólne; przede wszystkim zdaniem Sandela - łatwiej będzie im odrzucić troskę o własny interes jako źródło motywacji politycznej (Sandel, 1998, s. 325 za: Honohan, 2002, s. 217).

\section{Podsumowanie}

Instrumentalny republikanizm, rozwijany przede wszystkim w pracach Pettita, opiera się na założeniu, że wolność polityczna stanowi wartość stricte instrumentalną, służącą osiąganiu wolności jako nie-dominacji (która - jak wskazałam wcześniej - pełni w myśli Pettita rolę wartości konstytutywnej dla w pełni ludzkiego życia). Przyznanie wolności politycznej takiej jedynie ,służebnej” funkcji prowadzi do wyraźnego ograniczenia jej zakresu. Wydaje się, że nadanie tak wąskiej funkcji wolności politycznej jest niekorzystne z perspektywy koncepcji nie-dominacji, gdyż w wyznaczonym przez Pettita zakresie wolność polityczna nie realizuje podstawowej funkcji, którą w jego przekonaniu musi spełniać (to jest, nie sprzyja albo sprzyja jedynie w ograniczonym zakresie osiąganiu stanu nie-dominacji). Głosowanie w wyborach, które stanowi w jego przekonaniu podstawową formę wolności politycznej, nie pozwala trafnie identyfikować istotnych opinii i interesów obywateli ze względu na ograniczoną racjonalność decyzji wyborczych. Tym samym wybory nie pozwalają (albo pozwalają jedynie w ograniczonym stopniu) zrealizować wymóg braku substancjalnej arbitralności, a więc warunek nie-dominacji. Rozszerzenie ,autorskich" kompetencji obywateli byłoby więc posunięciem korzystnym z punktu widzenia realizacji ideału nie-dominacji. Ponadto Pettit, skupiając się wyłącznie na instrumentalnej roli wolności politycznej, zdaje się nie dostrzegać czy też nie uznawać jej głębszego wymiaru jako wartości (zarzut aksjologiczny). Przyjmując odmienne stanowisko, można argumentować, jak Arendt, że wolność polityczna jest wartością konstytutywną dla w pełni ludzkiego życia, chociaż - jak wskazałam - stanowisko to wydaje się trudne do przyjęcia 
bez zastrzeżeń. Można również, idąc śladami Tocqueville’a, uznać, że wolność polityczna jest co prawda wartością instrumentalną, ale aksjologicznie głębszą, pełniącą szczególnie subtelną rolę przeciwdziałania niektórym społecznym i psychologicznym „efektom ubocznym" demokracji równościowej. Przyjęcie któregoś z tych stanowisk nie oznacza oczywiście negowania podstawowej, czysto instrumentalnej roli wolności politycznej, która sprowadza się do manifestowania interesów czy wyrażania sprzeciwu wobec określonych działań władzy. Wydaje się jednak, że pełne korzystanie z dobrodziejstw wolności politycznej wymaga uznania jej za wartość wielowymiarową: zarówno środek sprawowania i kontroli władzy czy podejmowania decyzji, jak i szczególnie wartościową i satysfakcjonującą aktywność zasługującą na zaangażowanie. Przyjęcie takiego głębszego uzasadnienia wolności politycznej może bowiem prowadzić do ograniczenia roli krótkowzrocznych interesów jako źródła motywacji dla działania politycznego.

\section{Bibliografia}

Arendt, H. (2011). Co to jest wolność? (M. Godyń, tłum.). W: H. Arendt, Między czasem minionym a przysztym (s. 175-209). Warszawa: Wydawnictwo Aletheia.

Arendt, H. (2010). Kondycja ludzka. (A. Łagodzka, thum.). Warszawa: Wydawnictwo Aletheia.

Arystoteles. (2011). Polityka. (L. Piotrowicz, thum.). Warszawa: Wydawnictwo Naukowe PWN.

Berlin, I. (1994). Cztery eseje o wolności. (H. Bartoszewicz, D. Grinberg, D. Lachowska, A. Tanalska-Dulęba, tłum.). Warszawa: Wydawnictwo Naukowe PWN

Canovan, M. (2008). Lud. (S. Szymański, tłum.). Warszawa: Wydawnictwo Sic!

Canovan, M. (2002). Hannah Arendt: A reinterpretation of her political thought. Cambridge, UK: Cambridge University Press.

Carter, I. (2004). A measure of freedom. Oxford, UK: Oxford University Press.

Carter, I. (2000). Review: A critique of freedom as non-domination. The Good Society, 9(3), 43-46.

Ciszewski, W. (2017). Czy idea republikańskiej neutralności jest możliwa do zrealizowania? W: Kierunki badawcze w filozofii 2017 „Nowe horyzonty wiedzy” (s. 19-28). Łódź: Wydawnictwo Biblioteka.

Dagger, R. (1997). Civic virtues: Rights, citizenship, and republican liberalism. Oxford, UK: Oxford University Press.

de Tocqueville, A. (1994). Dawny ustrój i rewolucja. (H. Szumańska-Grossowa, tłum.). Kraków: Społeczny Instytut Wydawniczy Znak.

de Tocqueville, A. (1976). O demokracji w Ameryce. (M. Król, thum.). Warszawa: Państwowy Instytut Wydawniczy.

Eliasz, K., Załuski W. (2017). Legal values: Freedom. W: M. Sellers, S. Kirste (red.), Encyclopedia of the philosophy of law and social philosophy. Berlin, Niemcy: Springer. 
Elster, J. (2009). Alexis de Tocqueville: The first social scientist, Cambridge, UK: Cambridge University Press.

Elster, J. (1986). The market and the forum: Three varieties of political theory. W: J. Elster, A. Hylland (red.), Foundations of social choice theory (s. 103-132). Cambridge, UK: Cambridge University Press.

Hamilton, L. (2014). Freedom is power: Liberty through political representation. Cambridge, UK: Cambridge University Press.

Hobbes, T. (2009). Lewiatan. (C. Znamierowski, thum.). Warszawa: Fundacja Aletheia.

Honohan, I. (2002). Civic republicanism. London, UK: Routledge

Laborde, C., Maynor, J. (2008). The republican contribution to contemporary political theory. W: C. Laborde, J. Maynor (red.), Republicanism and political theory. Malden, MA: Blackwell Publishing

Larmore, C. (2008). The autonomy of morality. Cambridge, UK: Cambridge University Press

Lovett, F. (2017). Republicanism. W. E. N. Zalta (red.), The Stanford Encyclopedia of Philosophy (Spring 2017 Edition). Pobrane z: https://plato.stanford.edu/archives/spr2017/entries/republicanism/

Lovett, F. (2010). A general theory of domination \& justice. Oxford, UK: Oxfrod University Press.

Lüders, S., Müller-Salo, J. W. (2016). Which liberalism, which republicanism? Constructing traditions of political thought with Philip Pettit. W: S. Derpmann, D. P. Schweikard (red.), Philip Pettit: Five themes from his work. Heidelberg, Niemcy: Springer.

Maynor, J. (2006). Modern republican democratic contestation: A model of deliberative democracy. W: I. Honohan, J. Jennings (red.), Republicanism in theory and practice (s. 125-139). London, UK: Routledge.

Maynor, J. (2002). Another instrumental republican approach? European Journal of Political Theory, 1(1), 71-89.

Patten, A. (1996). The republican critique of liberalism. British Journal of Political Science, 26(1), $25-44$.

Pettit, P. (2014). Just freedom: A moral compass for the complex world. London, UK: W. W. Norton \& Company.

Pettit, P. (2012). On the people's terms: A republican theory and model of democracy. Cambridge, UK: Cambridge University Press.

Pettit, P. (2001). A theory of freedom: From the psychology to the politics of agency. Cambridge, UK: Polity Press.

Pettit, P. (1999). Republican freedom and contestatory democratization. W: I. Shapiro, C. HackerCordon (red.), Democracy's value (s. 163-190). Cambridge, UK: Cambridge University Press.

Pettit, P. (1997). Republicanism: A theory of freedom and government. Oxford, UK: Oxford University Press. 
Pocock, J. G. A. (2016). The Machiavellian moment: Florentine political thought and the Atlantic republican tradition. Princeton, NJ: Princeton University Press.

Rawls, J. (2012). Liberalizm polityczny. (A. Romaniuk, thum.). Warszawa: Wydawnictwo Naukowe PWN.

Riker, W. (1988). Liberalism against populism: A confrontation between the theory of democracy and the theory of social choice. Long Grove, IL: Waveland Press.

Skinner, Q. (2013). Wolność przed liberalizmem. (A. Czarnecka, tłum.). Toruń: Wydawnictwo Naukowe Uniwersytetu Mikołaja Kopernika.

Skinner, Q. (2008). Freedom as the absence of arbitrary power. W: C. Laborde, J. Maynor (red.), Republicanism and political theory (s. 83-101). Malden, MA: Blackwell Publishing

Skinner, R. (1999). The republican ideal of political liberty. W: G. Bock, Q. Skinner, M. Viroli (red.), Machiavelli and republicanism (s. 293-309). Cambridge, UK: Cambridge University Press.

von Hayek, F. A. (2006). Konstytucja wolności. (J. Stawiński, thum.). Warszawa: Wydawnictwo Naukowe PWN.

Załuski, W. (2015). Proces podejmowania decyzji wyborczych w świetle psychologii kognitywnej i neuronauki. W: M. Mączyński (red.), Praktyka realizacji biernego prawa wyborczego $w$ Polsce (s. 205-217). Warszawa: Wydawnictwo Diffin.

\title{
A Critique of Philip Pettit's Neo-Republican Conception of Political Freedom
}

\begin{abstract}
The aim of this article is a reconstruction and critique of the conception of political freedom as understood in contemporary instrumental republicanism represented primarily by Philip Pettit. Instrumental republicanism endows political freedom with a merely instrumental value, serving as a means to achieving non-domination which, on republican assumptions, is of chief importance. From the claim that the value of political freedom is merely instrumental follows a significant limitation of its scope (since outcomes of political freedom are potentially dominating). In this article I claim that Pettit's arguments are vulnerable to two main objections. First, a significantly limited scope of political freedom does not foster non-domination. Second, having focused on the merely instrumental value of political freedom, Pettit does not acknowledge the deeper dimension of political freedom as a democratic value.
\end{abstract}

Keywords: political freedom; non-domination; instrumental republicanism; arbitrariness; instrumental value; Philip Pettit. 